\title{
Incidence of Ascardia Gali in Cattle Egret (Bubulcus Ibis)
}

\section{Bhupesh Kamdi*, Suresh Jadhav, Sachin Raut, Rahul Pande, Prashant Sonkusale, NiTIN KURKURE}

\section{Department of Veterinary Pathology, Nagpur Veterinary College, Seminary Hills, Nagpur-440006, Maharashtra India.}

\begin{abstract}
Indian cattle egret birds of about one and half year old were presented to the department of veterinary pathology for the necropsy investigation by the forest officials of seminary hills Nagpur. Systemic necropsy examination revealed congested small intestine which had small thread like round worms. Further these worms were confirmed to be Ascardia galli depending on their morphological characteristics. Microscopically intestine revealed sloughing of villi and heterophilic infiltration.

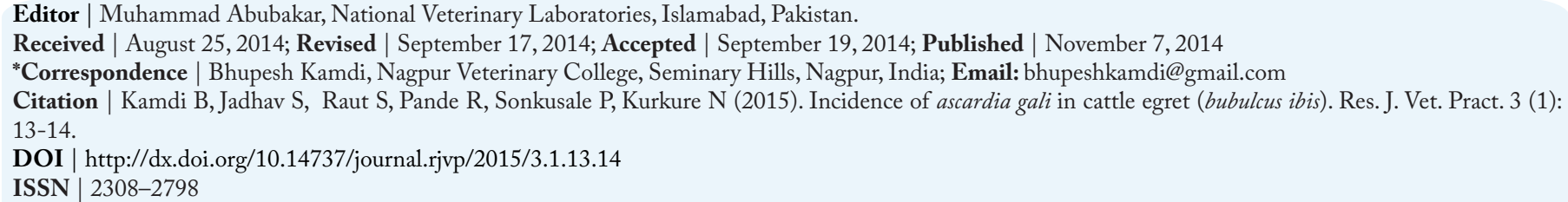

Copyright $\odot 2015$ Kamdi et al. This is an open access article distributed under the Creative Commons Attribution License, which permits unrestricted use, distribution, and reproduction in any medium, provided the original work is properly cited.

$\mathrm{T}$ The Cattle Egret (Bubulcus ibis) is a popular bird with cattle ranchers for its perceived role as a biological control of cattle parasites such as ticks and flies. It is a cosmopolitan species which belongs to family Ardeidae. They are found in the tropics, subtropics and warm temperate zones. It is the only member of themonotypic genus Bubulcus.

Large populations of captive wild birds are exposed to many parasitic diseases. Particularly helminth infections are major problem causing even mortality in captive animals and birds. Ascardia galli is the largest nematode of birds residing in the small intestine. It is the most prevalent and pathogenic parasite of domestic fowl. Parasite infestation can observe in other species of birds also which causes anorexia, weight loss, hemorrhages in the intestinal mucosa and obstruction in intestinal lumen (Permin et al., 2006). Limited information is available about the incidence of Ascardia galli in cattle egret from central India. Therefore present communication aims to report the incidence of Ascardia galli in cattle egret from central India.

Three Indian cattle egret birds about one and half year old were presented to the department of veterinary pathology for the necropsy examination by the forest officials of seminary hills Nagpur. Systemic necropsy examination was carried out. Necropsy examination revealed congested small intestine having small thread like round worms which were collected in normal saline, washed several times in it and then preserved it in $70 \%$ alcohol for further identification. Affected portion of intestine was collected in $10 \%$ buffered formal saline solution for the histopathological investigation. Intestine where processed by routine procedure to obtain $5 \mu \mathrm{m}$ thick sections from paraffin embedded blocks and stain with hematoxaline and eosine stain (Luna, 1968).

The round worms found during necropsy examination were confirmed as Ascardia galli according to Soulsby (1982). All the worms were present in the small intestine had length of 80 to $95 \mathrm{~mm}$. Worm had three large lips and oesophagus with no posterior bulb, precloacal sucker was circular with circular rim and spicule of the worms was sub equal (Figure 1). Histopathological examination of affected portion of intes January 2015 | Volume 3 | Issue 1 | Page 13 


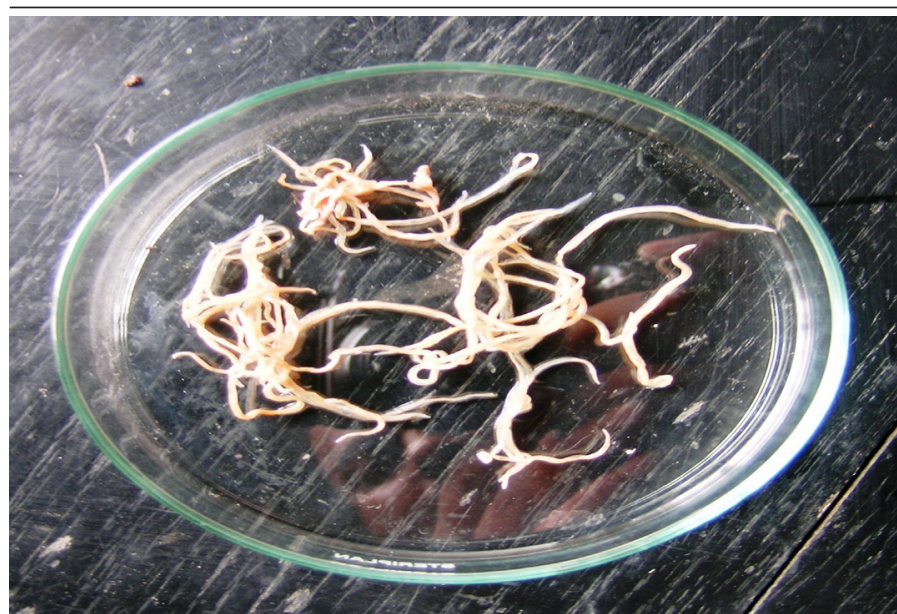

Figure 1: Showing Ascardia galli worms collected from intestine of birds

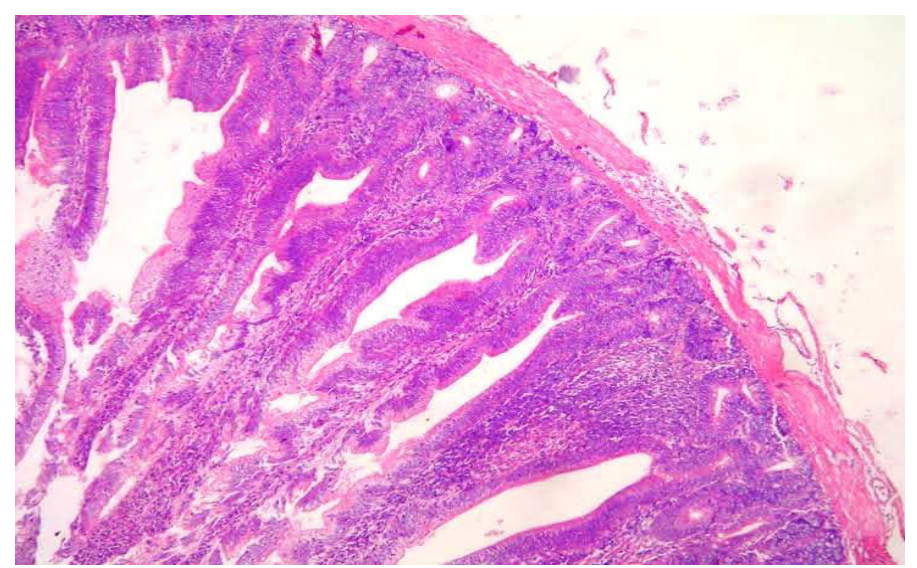

Figure 2: Section of intestine showing sloughing of villli and heterophillic infiltration)

tine revealed inflammatory reaction with heterophilic cells infiltration, sloughing of intestinal villi (Figure 2). Earlier, the Patel et al. (2000) reported prevalence of gastrointestinal parasites in captive birds of Gujrat Zoo, Parsani et al., (2003) found the $71.43 \%$ prevalence of Ascardia species in captive birds at Kamla Nehru Zoological garden, Kankaria Zoo, Ahmadabad Gujarat, Borghare et al. (2009) recorded the incidence of Ascardia species upto $76.66 \%$ in captive wild pigeons at Nagpur.

\section{CONFLICT OF INTEREST}

Author declares no conflict of interest.

\section{REFERENCES}

- Borghare AT, Bagde VP, Jaulkar AD, Katre DD, Jumde P D, Maske DK, Bhangale GN (2009). Incidence of Gastrointestinal parasitism of Captive Wild Pigeons at Nagpur. Vet. World. 2(9): 343.

- Luna AG (1968). Manual of histological staining methods of the Armed Forced Institute of Pathology. 3rd ed. McGraw Hill book co., London. 124 -125.

- Parsani HR, Momin RR, Sahu RK, Patel BG (2003). Prevalence of gastrointestinal parasite in captive birds at Kamla Nehru Zoological garden, Kankaria Zoo, Ahmadabad Gujarat. Zoo's Print J. 18 (1): 987992.

- Patel PV, Patel AI, Sahu RK, Vyas R (2000). Prevalence of gastrointestinal parasites in captive birds of Gujrat Zoo. Zoo's Print J. 15(7): 295.

- Permin A, Christensen JP, Bisgaard M (2006). Consequences of concurrent Ascaridia galli and Escherichia coli infections in chickens. Acta vet. scand. 47(1): 43-54.

- Soulsby EJL (1982). Helminths, Arthropods and Protozoa of Domesticated Animals. 7th Edition. ELBS and Bailliere Tindall, London. 